\title{
KEABSAHAN AKAD JUAL BELI MULTI LEVEL MARKETING DALAM PERSPEKTIF TEORI HUKUM PERJANJIAN SYARI'AH (NAZHÂRIYYAT AL-'UQÛD)
}

\author{
Iskandar Mirza \\ Direktur Eksekutif Imtaq Foundation \\ Email: iskandarmirza@yahoo.com
}

\begin{abstract}
According to the form of legal development (al-tasyrî́), nazhâriyyat al-'uqûd is resulted from the transformation process of sources, principles, and bases of Islamic economic values which are derived from the Quran and the Sunna into the pracstical of Islamic business. It is also firstly begun through the analysis and translation on nazhâriyyat al-'uqûd by the muslim scholars in the book of figh. The concept of business transaction (mafhum al-'uqûd) in Islamic legal contract is based on three theories: First, the theory of property rights (nazhâriyyat al-milkiyyah 'alâ al-mâl); Second, the theory of business transaction (nazhâriyyat al-'uqûd); and Third, the theory of property management (nazhâriyyat al-intiqal al-milkiyyah). These are starting point to examine the consept of business transaction (mafhum al-'uqûd) within Islamic legal contract to dealth with the Islamic practical rule of direct selling.
\end{abstract}

\begin{abstract}
Abstrak
Di lihat dari sudut pandang pembentukan hukum (al-tasyrî́), nazhâriyyat al-'uqûd dalam hukum perikatan Islam merupakan sebuah hasil dari transformasi sumber, prinsip dan asas ekonomi Islam yang didasarkan kepada al-Quran dan Sunnah ke dalam bahasa praksis bisnis Islam, dengan terlebih dahulu dilakukan penelaahan dan penterjemahan atas konsep-konsep nazhâriyyat al-'uqûd dalam hukum perikatan Islam oleh para fuqahâ' dari kitab-kitab fikih. Konsep akad (mafhum al-'uqûd) dalam hukum perikatan Islam didasarkan kepada tiga teori: Pertama, teori kepemilikan atas harta (nazhâriyyat al-milkiyyah 'ala al-maal); Kedua, teori perjanjian atau akad (nazhâriyyat al-'uqûd); dan Ketiga, teori peralihan kepemilikan (nazhâriyyat al-intiqal almilkiyyah). Ketiga teori itu merupakan diduga kuat dapat menjadi pijakan awal untuk menjelaskan konsep akad (mafhum al-'uqûd) dalam hukum perikatan Islam hubungannya dengan praktik bisnis jual beli Multi Level Marketing (MLM).
\end{abstract}

Kata Kunci:

Ekonomi Islam, Business Transaction, Property Rights, Direct Selling

\section{A. Pendahuluan}

Konsep akad dalam perspektif filsafat ilmu hukum perikatan Islam dan kaitannya dengan hukum transaksi bisnis di Indonesia serta tata cara akad dan tujuannya erat kaitannya dengan pembahasan tentang akad (al-'aqd). Akad dalam bahasa Indonesia disebut kontrak merupakan konsekuensi logis dari hubungan sosial dalam kehidupan manusia. Hubungan ini merupakah fitrah yang sudah ditakdirkan oleh Allah ketika menciptakan makhluk yang bernama manusia. Oleh karena itu, ia merupakan kebutuhan sosial sejak manusia mulai mengenal arti hak milik. Islam sebagai agama yang komprehensif dan universal telah memberikan aturan yang cukup jelas tentang akad untuk dapat diimplementasikan dalam setiap masa.

Oleh karena itu, dalam filsafat ilmu hukum perikatan Islam dikenal banyak jenis akad, yang umumnya dilihat dari segi apakah akad dan hak milik tersebut diperbolehkan oleh syara' atau tidak; dilihat dari segi bagaimana akad tersebut dilaksanakan; dilihat dari segi apakah akad itu bernama atau tidak; dilihat dari segi tujuan diselenggarakannya 
akad, dan lain-lain. Masing-masing akad memiliki karakteristik dan jenisnya sesuai dengan tujuan dilaksanakannya akad itu sendiri.

Berkenaan dengan hal tersebut, dewasa ini masih terdapat silang pendapat mengenai hokum transaksi bisnis jual beli Multi Level Marketing (MLM), terutama jika dilihat dari perspektif hukum ekonomi syari'ah. Oleh karena itu, tulisan ini akan menjelaskan secara ringkas tentang keabsahan akad jual beli multi level marketing dalam perspektif teori hukum perjanjian syari'ah (nazhâriyyat al-'uqûd) melalui pendekatan filsafat ilmu hukum perikatan Islam.

\section{B. Konsep Akad dalam Hukum Perikatan Islam}

Dalam bahasa Arab, akad berasal dari kata 'aqada - yu'aqqidu - 'uqûdan, yang secara bahasa berarti mengikat, mengunci, menahan, atau membuat suatu perjanjian. ${ }^{1}$ Selain itu, akad juga diambil dari beberapa istilah dalam bahasa Arab yang memiliki makna sejenis, antara lain: ${ }^{2}$

Pertama, berasal dari kata ikatan (الربط), yaitu mengumpulkan dua ujung tali dan mengikat salah satunya dengan yang lain saling mengikat sehingga menjadi bersambung, yang kemudian keduanya menjadi sepotong benda.

Kedua, berasal dari katan sambungan (عقدة), yaitu sambungan yang memegang kedua ujung itu dan mengikatnya.

Ketiga, berasal dari kata janji (العها), sebagaimana tercantum dalam QS.. Âli-'Imrân ayat 76 yang berbunyi:

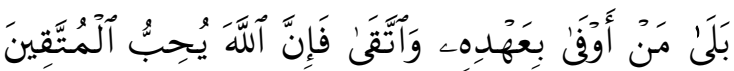

(Bukan demikian), sebenarnya siapa yang menepati janji (yang dibuat)nya dan bertakwa, maka sesungguhnya

Ikhwan Abidin Basri, Teori Akad dalam Fikih Muamalah, kutipan artikel dalam http://www.fossei.4t.com/Artikel14.htm, diakses tanggal15 Januari 2010.

2 Lihat beberapa pengertian akad dalam hukum ekonomi Islam, sebagaimana dijelaskan oleh Hendi Suhendi, Fikih Muamalah (Jakarta: Raja Grafindo Persada. 2002), hlm. 44-46.
Allah menyukai orang-orang yang bertakwa. ${ }^{3}$

Keempat, berasal dari kata perjanjian (العقود), sebagaimana tercantum dalam QS. alMâidah ayat 1 yang berbunyi:

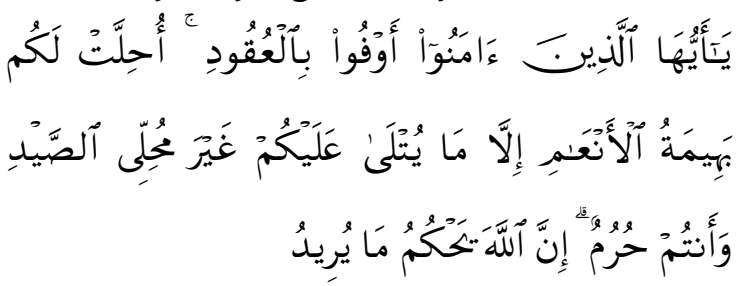

Hai orang-orang yang beriman, penuhilah aqad-aqad itu, dihalalkan bagimu binatang ternak, kecuali yang akan dibacakan kepadamu. (yang demikian itu) dengan tidak menghalalkan berburu ketika kamu sedang mengerjakan haji. Sesungguhnya Allah menetapkan hukumhukum menurut yang dikehendaki-Nya. ${ }^{4}$

Nibra Hoesen menjelaskan teori akad dalam hukum perikatan Islam,bahwa akad dapat diartikan gabungan atau penyatuan dari penawaran (ijab) dan penerimaan (qabul) yang sah sesuai dengan hukum Islam. ljab artinya penawaran dari pihak pertama, sedangkan qabul adalah penerimaan dari pihak kedua. Dengan kata lain, yang dimaksud dengan akad menurut istilah adalah suatu perjanjian serah terima barang antara dua orang yang dilakukan secara sukarela baik langsung maupun tidak langsung. ${ }^{5}$

Sedangkan menurut pengertian istilah, akad berarti ikatan antara ijab dan qabul yang diselenggarakan menurut ketentuan syariat di mana terjadi konsekuensi hukum atas sesuatu yang karenanya akad diselenggarakan. Pengertian ini bersifat lebih khusus karena terdapat pengertian akad secara istilah yang lebih luas dari pengertian ini. $\mathrm{Na}$ mun ketika berbicara mengenai akad dalam konteks hukum perikatan Islam, pada umum-

3 Software Qur'an in Word.

4 Ibid.

5 Nibra Hoesen, Pengerrtian Akad dalam Transaksi Syari'ah, diterjemahkan dari, Aplied Shariah in Financial Transaction, The Requirement of Shariah in Financial Transactions (Kuala Lumpur: INCEIF. 2006) diakses melalui http://nibrahosen.multiply.com/journal/item/5, diakses tanggal 15 Januari 2010. 
nya pengertian inilah yang paling luas dipakai oleh kebanyakan fuqahâ'.

Adapun pengertian akad yang bersifat lebih umum mencakup segala diinginkan (diazamkan) orang untuk dilakukan baik itu yang muncul karena kehendak sendiri (irâdah munfaridah), seperti: wakaf, cerai dan sumpah maupun yang memerlukan dua kehendak (irâdatayn) untuk mewujudkannya, seperti: jual beli, sewa menyewa, perwakilan dan gadai. Berdasarkan pengertian akad yang lebih umum tersebut, muncul sedikit perbedaan dengan akad yang dimengerti oleh para fuqahâ' dan hukum-hukum perdata konvensional. Perbedaannya adalah bahwa dalam pengertian yang lebih luas mencakup kehendak tunggal dapat melazimkan suatu transaksi, sementara menurut undangundang hukum perdata konvensional akad mesti melibatkan dua kehendak. Karena itu wilayah akad dalam pengertian umum jauh lebih luas dibandingkan dengan akad dalam pengertian khusus.

Selanjutnya dilihat aspek efistimologi ilmu hukum perikatan Islam, dapat dipahami bahwa mengacu kepada beberapa pengertian dalam teori akad di atas, tampaknya ada beberapa unsur yang termasuk ke dalam rukun akad ada tiga, yaitu: ${ }^{6}$

Pertama, sighat yaitu pernyataan ijab dan qabul dari kedua belah pihak, boleh dengan lafaz atau ucapan, boleh juga di lakukan dengan tulisan. Sighat, haruslah selaras antara ijab dan qabul-nya. Apabila satu pihak menawarkan (ijab) benda A dengan harga seratus rupiah, pihak lain harus menerima (qabul) dengan menyebutkan benda A senilai seratus rupiah pula, bukan benda B yang harganya 150 rupiah. Dalam sighat kedua belah pihak harus jelas menyatakan penawaran nya dan pihak yang lain harus dengan jelas menerima tawarannya (transparansi), qabul harus langsung di ucapkan setelah ijab di ucapkan, ijab dan qabul haruslah terko-

6 Lihat penjelasan Nibra Hosen, Briefcase Book Edukasi Professional Syariah, Cara Mudah Memahami Akad-akad Syariah, tim penyunting: Muhammad Firdaus NH, Sofiniah Ghufron, Muhammad Aziz Hakim, Mukhtar Alshodiq (Kuala Lumpur: INCEIF. 2006), dipublikasika dalam http://nibrahosen.multiply.com/journal/item/5, diakses tanggal 15 Januari 2010. neksi satu dengan yang lain tanpa adanya halangan waktu dan tempat. Misalnya ijab ditawarkan hari ini dan dijawab dua hari kemudian itu tidaklah sah, ijab dan qabul juga harus dilakukan di dalam satu ruangan yang sama oleh kedua belah pihak atau istilahnya harus di dalam satu majelis yang sama.

Kedua, 'aqidayn yaitu pihak-pihak yang akan melakukan akad, kedua belah pihak yang akan melaksanakan akad ini harus sudah mencapai usia akil-baligh (sesuai hukum yang berlaku di suatu negara), harus dalam keadaan waras (tidak gila) atau mempunyai akal yang sehat, harus dewasa (rushd) dan dapat bertanggungjawab dalam bertindak, tidak boros, dan dapat dipercaya untuk mengelola masalah keuangan dengan baik.

Ketiga, mahal al-'aqd atau obyek-obyek akad yaitu jasa atau benda-benda yang berharga dan obyek akad tersebut tidak dilarang oleh syariat. Obyek akad yang dilarang atau diharamkan oleh syariat diantaranya adalah minuman keras, darah, bangkai, dan daging babi.

Secara umum, akad dibagi menjadi tiga kategori sebagai berikut: pertama, akad mu'jiz yaitu akad yang dilaksanakan langsung pada waktu selesainya akad; kedua, akad mu'allaq yaitu akad yang dalam pelaksanaannya terdapat syarat-syarat yang telah ditentukan dalam akad, seperti penentuan serah terima barang yang diakadkan setelah adanya pembayaran; dan ketiga, akad mudlaf yaitu akad yang dalam pelaksanaannya terdapat syarat-syarat mengenai penanggulangan pelaksanaan akad, pernyataan yang pelaksanaannya ditangguhkan hingga waktu yang ditentukan. Akad tersebut dapat dianggap sah dilakukan pada saat akad, meskipun belum mempunyai akibat hukum sebelum tibanya waktu yang telah ditentukan.

Mengacu kepada syarat dan rukun akad di atas, maka untuk memperoleh keberkahan dalam jual beli, Islam telah mengajarkan tata cara akad dengan tetap berpegang kepada etika ekonomi Islam, sebagai berikut:

1. Jujur dalam takaran dan timbangan, Allah berfirman QS. al-Muthaffifîn ayat 1-2 yang artinya: "Celakalah bagi orang yang curang. Apabila mereka menimbang dari lain (untuk dirinya, dipenuhkan tim- 
bangannya). Namun, apabila mereka menimbang (untuk orang lain) dikuranginya";

2. Menjual barang yang halal. Dalam salah satu hadits Nabi menyatakan bahwa Allah telah mengharamkan sesuatu barang, maka haram pula harganya (diperjualbelikan);

3. Menjual barang yang baik mutunya. Dalam berbagai hadits Rasulullah melarang menjual buah-buahan hingga jelas baiknya;

4. Jangan menyembunyikan cacat barang. Salah satu sumber hilangnya keberkahan jual beli, jika seseorang menjual barang yang cacat yang disembunyikan cacatnya. Ibnu 'Umar menurut riwayat Bukhârî, telah memberitakan bahwa seorang lelaki menceritakan kepada Nabi bahwa ia tertipu dalam jual beli. Sabda Nabi: “Apabila engkau berjualbeli, katakanlah: tidak ada tipuan";

5. Dilarang bermain sumpah. Ada kebiasaan pedagang untuk meyakinkan pembelinya dengan jalan main sumpah agar dagangannya laris. Dalam hal ini Rasulullah SAW memperingatkan: "Sumpah itu melariskan dagangan, tetapi menghapuskan keberkahan". (HR. Bukhârî);

6. Longgar dan bermurah hati. Sabda Rasulullah: "Allah mengasihi orang yang bermurah hati waktu menjual, waktu membeli dan waktu menagih hutang". (HR. Bukhârî). Kemudian dalam hadits lain Abû Hurayrah meriwayatkan bahwa Rasulullah bersabda: "Ada seorang pedagang yang mempiutangi orang banyak. Apabila dilihatnya orang yang ditagih itu dalam dalam kesempitan, dia perintahkan kepada pembantu-pembantunya." Berilah kelonggaran kepadanya, mudah-mudahan Allah memberikan kelapangan kepada kita". Maka Allah pun memberikan kelapangan kepadanya". (H.R. Bukhârî);

7. Jangan menyaingi kawan. Rasulullah telah bersabda: "Janganlah kamu menjual dengan menyaingi dagangan saudaranya";

8. Mencatat hutang piutang. Dalam dunia bisnis lazim terjadi pinjam-meminjam. Dalam hubungan ini al-Quran mengajarkan pencatatan hutang piutang. Gunanya ada- lah untuk mengingatkan salah satu pihak yang mungkin suatu waktu lupa atau khilaf, sebagaimana ditegaskan dalam QS. al-Baqarah ayat 282 yang berbunyi: "Hai orang-orang yang beriman, kalau kalian berhutang-piutang dengan janji yang ditetapkan waktunya, hendaklah kalian tuliskan. Dan seorang penulis di antara kalian, hendaklah menuliskannya dengan jujur. Janganlah penulis itu enggan menuliskannya, sebagaimana telah diajarkan oleh Allah kepadanya";

9. Larangan riba sebagaimana Allah telah berfirman: "Allah menghapuskan riba dan menyempurnakan kebaikan shadaqah. Dan Allah tidak suka kepada orang yang tetap membangkang dalam bergelimang dosa"; dan

10. Anjuran berzakat, yakni menghitung dan mengeluarkan zakat atas harta yang dimiliki atau barang dagangan setiap tahun sebanyak $2,5 \%$ sebagai salah satu cara untuk membersihkan harta yang diperoleh dari harta yang dimiliki atau perolehan keuntungan hasil usaha.

Berdasarkan uraian di atas, maka dilihat dari segi efistimologi ilmu hukum perikatan Islam, setiap pelaku bisnis (wirausaha) dalam berdagang, hendaknya tidak semata-mata bertujuan mencari keutungan sebesarbesarnya, akan tetapi yang paling penting adalah mencari keridhaan dan mencapai keberkahan atas rezeki yang diberikan oleh Allah SWT. Hakikat keberkahan usaha itu adalah kemantapan dari usaha yang dilakukannya dalam bentuk memperoleh keuntungan yang wajar dan diridhai oleh Allah SWT.

Kemudian dilihat dari segi tujuannya, akad mencakup beberapa tujuan penting yaitu akad tamlîk, syirkah, tautsiq, amânah, dan tasharuf. Akad tamlîk yaitu suatu akad yang dilakukan dua orang lebih dengan tujuan untuk memiliki harta. Misalnya, dua orang bersepakat melakukan pemindahan hak milik melalui akad jual beli (al-bay'). Akad syirkah yaitu suatu akad yang dilakukan oleh dua orang atau lebih dengan tujuan bersepakat untuk memiliki dan mengelola harta secara bersama-sama. Misalnya, dua orang 
bersepakat untuk mengelola usaha bersama dengan cara musyarakah atau mudlarabah.

Sedangkan akad tautsiq yaitu suatu akad yang dilakukan oleh dua orang atau lebih dengan tujuan untuk memelihara kepercayaan di antara kedua belah pihak. Misalnya, salah satu pihak menitipkan hartanya kepada yang lain untuk dikelola. Akad amânah yaitu suatu akad yang dilakukan oleh dua orang atau lebih dengan tujuan untuk memelihara kepercayaan di antara kedua belah pihak. Misalnya, salah satu pihak menitipkan hartanya kepada yang lain untuk dikelola. Akad tasharuf yaitu suatu akad yang dilakukan oleh dua orang atau lebih dengan tujuan untuk mengelola harta tersebut oleh salah satu pihak. Misalnya, salah satu pihak menitipkan hartanya kepada yang lain untuk dikelola.

Di samping itu, ada beberapa teori perjanjian/akad (nazhâriyyat al-'uqûd) dapat digunakan untuk menjelaskan segala bentuk hak milik atas harta, baik individu maupun kolektif, diatur sedemikian rupa melalui pengelolaan (tasharruf 'alâ al-mâl) yang dibenarkan menurut ketentuan syara'. Dalam konteks ini, nazhâriyyat al-'uqûd dalam hukum perikatan Islam salah satunya disandarkan kepada ketentuan nash QS. al-Baqarah ayat $1,{ }^{7}$ bahwa perjanjian bisnis termasuk dalam kategori akan yang direfleksikan sumbernya (al-Quran dan Sunnah), antara lain:

Pertama, menurut teori niat (nazhâriyyat al-ta'bir), ketentuan hukum semua perkataan dan perbuatan manusia, termasuk dalam hal pengelolaan harta sangat bergantung kepada niatnya dan bukan semata-mata bersandar kepada lahiriahnya saja. Praktik pengelolaan harta menurut teori niat hukumnya boleh sepanjang ditujukan untuk kebaikan dan tidak bertentangan dengan hukum syara'. Hal ini didasarkan kepada kaidah fikih yang berbunyi: Akad transaksi itu adalah maksud dan niat, bukan lafadz dan pernya-

7 Terjemah: "Hai orang-orang yang beriman, penuhilah aqad-aqad itu. dihalalkan bagimu binatang ternak, kecuali yang akan dibacakan kepadamu. (yang demikian itu) dengan tidak menghalalkan berburu ketika kamu sedang mengerjakan haji. Sesungguhnya Allah menetapkan hukum-hukum menurut yang dikehendaki-Nya". (QS. al-Mâidah ayat 1) taan" (al-ashl fî al-‘uqûd lil maqâshid wa alma'ânî lâ li al-fâdzi wa al-mabâni);

Kedua, menurut teori ungkapan keinginan (nazhâriyyat al-ta'bîr 'an al-irâdat) keinginan hati merupakan asas keterikatan tindakan perkataan, baik manyangkut akad ataupun bukan akad. Karena keinginan hati sulit dideteksi dan diverbalkan, maka setiap bentuk akad dapat didasarkan kepada wujud yang tampak dalam perkataan (al-Irâdaț). Pendek kata, pengelolaan harta milik melalui praktik transaksi bisnis MLM dibenarkan hukumnya menurut syara' sepanjang dalam proses transaksi itu tidak ada lafaz hukum yang menyalahi nash ataupun mencederai salah satu pihak yang terlibat dalam akad;

Ketiga, menurut teori pemeliharaan kemaslahatan (nazhâriyyat al-mashlahah), semua transaksi bisnis untuk kepentingan akad dan pemilikan harta dapat dibolehkan apabila dilakukan sesuai ketentuan syara' dan tidak berdampak buruk (mafsadah). Dengan kata lain, jenis transaksi bisnis apapun tetap dibolehkan hukumnya menurut syara', sepanjang pihak-pihak yang melakukan transaksi bisnis, produk yang diperjualbelikan, serta keuntungan dan kerugiannya memberikan dampak positif (mashlahah) bagi yang bertransaksi.

\section{Prinsip-prinsip Hukum Perikatan Islam}

Secara substansial, prinsip-prinsip akad kepemilikan dalam filsafat ilmu hukum perikatan Islam erat kaitannya dengan perkembangan pemikiran tentang hukum ekonomi Islam (fikih muamalah). Fikih muamalah diartikan dalam dua makna yakni sebagai sistem ekonomi Islam dan hukum ekonomi Islam. Untuk makna yang pertama, fikih muamalah diartikan sebagai tata aturan dan mekanisme kerja untuk mengatur setiap usaha ekonomi yang dilakukan oleh individu atau badan hukum ekonomi. Adapun makna yang kedua, fikih muamalah dapat diartikan sebagai ketentuan normatif yang mengatur tentang tata aturan berekonomi.

Di antara kaidah-kaidah hukum yang harus diperhatikan dalam menerapkan hukum adalah: Pertama, mewujudkan keadilan bagi terpeliharanya hak-hak asasi manusia; Kedua, hukum dutujukan untuk kesejahtera- 
an dan kemakmuran masyarakat; Ketiga, hukum diberlakukan sesuai dengan kesepadanan dan tingkat kemampuan melaksanakannya; Keempat, setiap pelanggar hukum hendaknya diberikan sanksi dengan cara adil dan bijaksana; dan Kelima, harus ada keyakinan bagi setiap pelanggar hukum sama saja melawan semua ketentuan dari Allah dan RasulNya. ${ }^{8}$

Pada gilirannya, dari rumusan kaidahkaidah hukum tersebut penegakan hukum adalah yang paling utama, sebagaimana disinyalir dalam QS. al-Nisâ ayat 58, 105, dan 153, serta QS. al-Mâidah ayat 6. Penegakan hukum yang ditujukan untuk keadilan akan menjamin kemaslahatan bagi setiap individu. Hal ini hendaknya dilaksanakan dalam setiap tingkatan dan jenis hukum menurut ketentuan hukum Islam sebagaimana kaidah fiqh yang berbumyi: “Apa yang tidak bisa dilaksanakan seluruhnya, jangan ditinggalkan seluruhnya." (ما لا يدرك كله لا يترك كله).

Kendatipun dalam hal pengembangan hukum Islam merupakan tugas manusia untuk merekonstruksinya dalam fiqh tetapi prinsip-prinsip hukum Islam itu harus sejalan dengan asas-asas pembinaan hukum Islam yang menjadi fondasi utama, antara lain: 1) Tauhid dan eksistensi manusia dalam QS. albaqarah ayat 30, al-Nûr ayat 55 dan al-An'âm ayat 165 ; 2) Keadilan dalam QS. al-Nisâ ayat 58, al-Mâidah ayat 6 dan al-Nisâ ayat 105; 3) Musyawarah dalam QS. Âli-'Imrân ayat 159, al-Syurâ ayat 38 dan al-Nisâ ayat 49;4) Persamaan dalam QS. al-Nisâ ayat 1 dan alHujurât ayat 33; 5) Kebebasan dalam QS. alMâidah ayat 32, al-Nisâ ayat 58 dan al-Isrâ' ayat 33; 6) 'amr ma'ruf Nahyi Munkar dalam QS. Âli-'Imrân ayat 110 dan 114; 7) tolong menolong dalam QS. al-Mâidah ayat 2, alAnfâl ayat 11 dan al-Mâ'ûn ayat 1-3; dan 8) Toleransi dalam QS. al-Baqarah ayat 256, alAn'âm ayat 108, Yûnus ayat 99 dan alMumtahanah ayat $8 .{ }^{9}$

8 Hasbi Ash-Shiddiqie, Fakta Keagungan Syari'at Islam (Jakarta: Bulan Bintang. 1982), hlm. 25-26.

9 Soenarjo, dkk., al-Qur'an dan Terjemahnya (Jakarta: Depag RI. 1987). Sebagai perbandingan, Penulis mengambil beberapa rumusan tentang prinsipprinsip dan asas-asas hukum Islam, selain dari literatur tentang hukum Islam, juga diambil dari materi per-
Uraian tersebut menjukkan bahwa prinsip-prinsip dan asas-asas hukum ekonomi Islam dapat ditransformasikan dari figh ke dalam peraturan perundang-undangan yang berkaitan dengan hukum perikatan Islam (altarîkh al-syarî́ah fi al-taqnîn). Namun dalam kaitan ini, diperlukan suatu bentuk partisipasi kolektif yang dimulai dari gagasan dan kesadaran hukum Islam setiap muslim sampai kepada tingkat unifikasi dan kodifikasi hukum secara kolektif di tingkat pemerintahan dan negara.

Berkenaan dengan hal tersebut, karakteristik hukum Islam menjadi dasar bagi perumusan prinsip-prinsip akad dan hak milik dalam hukum ekonomi Islam erat kaitannya dengan etika ekonomi Islam dalam setiap kegiatan bisnis. Juhaya S. Praja menyebutkan terdapat beberapa prinsip hukum ekonomi Islam, yaitu: ${ }^{10}$

1. Prinsip lâ yakun dawlatan bayn al-agniyâ, yakni prinsip hukum ekonomi yang menghendaki pemerataan dalam pendistribusian harta kekayaan;

2. Prinsip 'an tarâdlin, yakni pemindahan hak kepemilikan atas harta yang dilakukan secara sukarela;

3. Prinsip tabâdul al-manâfi', yakni pemindahan hak atas harta yang didasarkan kepasa azas manfaat;

4. Prinsip takâful al-ijtimâ', yakni pemindahan hak atas harta yang didasarkan kepada kepentingan solidaritas sosial; dan

5. Prinsip haq al-lâh wa haq al-'adâmi, yakni hak pengelolaan harta kekayaan yang didasarkan kepada kepentingan milik bersama, di mana individu maupun kelompok dapat saling berbagi keuntungan serta diatur dalam suatu mekanisme ketatanegaraan di bidang kebijakan ekonomi.

Di samping prinsip-prinsip tersebut, dalam sistem hukum ekonomi Islam dijelaskan

kuliahan Filsafat Hukum Islam pada Program Pascasarjana IAIN Sunan Gunung Djati Bandung, di mana Prof. Dr. Juhaya S. Praja menjelaskannya secara terperinci dan sistematis tentang "Hierarki Hukum Islam." (diambil dari Hasil Materi Kuliah Filsafat Hukum Islam semester II-III tahun 1999 di PPS IAIN SGD Bandung).

10 Juhaya S. Praja, Orasi Ilmiah Pengukuhan Guru Besar Madya Filsafat Hukum Islam tentang “Rekonstruksi Paradigma IImu: Titik Tolak Pengembangan IImu Agama dan Universalitas Hukum Islam", pada tanggal 1 April 2000 di IAIN Sunan Gunung Djati Bandung. 
pula berbagai ketentuan yang terangkum dalam asas-asas muamalah. Ahmad Azhar Basyir telah menjelaskan tentang asas-asas muamalah dalam hukum ekonomi Islam, antara lain: ${ }^{11}$

1. Asas kehormatan manusia (QS. al-Isrâ' ayat 70);

2. Asas kekeluargaan dan kemanusiaan (QS. al-Hujurât: 13);

3. Asas gotong-royong dalam kebaikan (QS. al-Mâidah ayat 2);

4. Asas keadilan, kelayakan dan kebaikan (QS. al-Nahl ayat 90);

5. Asas menarik manfaat dan menghindari madharat (QS. al-Baqarah ayat 282);

6. Asas kebebasan dan kehendak (QS. AlBaqarah ayat 30); dan

7. Asas kesukarelaan (QS. al-Nisâ ayat 39). Prinsip-prinsip dan asas-asas muamalah tersebut merupakan pijakan mendasar bagi perumusan nilai-nilai dasar etika bisnis Islami. Demikian halnya untuk menjamin praktik bisnis yang sesuai dengan prinsip-prinsip dan asas-asas muamalah, umat muslim dapat menjabarkan berbagai bentuk akad (al-bay', musyarakah, mudlarabah, murabahah, qardl, rahn, dan sebagainya) di lembaga-lembaga keuangan syariah (bank dan non bank). Saat ini, penerapan prinsip-prinsip dan asas-asas muamalah pada lembaga keuangan syariah bukan lagi merupakan tuntutan umat muslim, tetapi telah menjadi kebutuhan umum.

Berkenaan dengan hal tersebut di atas, Islam memandang kegiatan akad dan pemilikan harta dengan cara jual beli sebagai perbuatan yang mulia sebab kegiatan ini bisa dijadikan salah satu sarana untuk beribadah atau mendekatkan diri kepada Allah SWT, selama kegiatan-kegiatan ini dilandasi dengan perintah-perintah-Nya. Prinsip yang harus dijalankan dalam kegiatan berdagang atau mencari nafkah lainnya, seperti yang diperintahkan dalam QS. al-Baqarah ayat 188 yang artinya: "Jangan mencarinya dengan jalan yang bathil", QS. al-Munâfiqûn ayat 9: "Jangan lupa berdzikir atau mengingat Allah", QS. al-Nûr ayat 37: "Jangan lupa untuk mengeluarkan zakat dan sedekah dari sebagian harta yang diperolehnya", dan QS. al-Hasyr ayat 7: "Jangan memusatkan harta kekayaan hanya kepada sekelompok orang saja".

11 Ahmad Azhar Basyir, Refleksi atas Persoalan Keislaman (Bandung: Mizan. 1994), hlm. 190-191.
Perintah-perintah tersebut bukan berarti menghambat apalagi melarang adanya kegiatan akad dan pemilikan harta melalui jual beli atau perdagangan, melainkan secara teologis menunjukkan bagaimana kegiatan tersebut dapat tegak sambil menjalankan kebaikan dan kebenaran yang bersumber kepada nilai-nilai ketuhanan (al-Quran) serta berusaha untuk memuliakan nilai-nilai kemanusiaan, sekaligus merupakan upaya dalam memakmurkan alam semesta ini.

Syariat Islam menganggap bahwa harta adalah termasuk lima tujuan yang harus dijaga dan dipelihara untuk mencapai kemaslahatan dan kebahagiaan manusia baik di dunia maupun di akhirat. Lima tujuan ini disebut dengan kebutuhan dlarûriyyah dalam kehidupan manusia, adalah sesuatu yang menjadi kebutuhan primer manusia untuk kemaslahatan hidupnya dan jika kebutuhan itu tidak terpenuhi, maka hidupnya di dunia dan akhirat akan berantakan, kekacauan dan kerusakan timbul di mana-mana, akibatnya kemaslahatan atau kebaikan itu akan lenyap dari kehidupan manusia. ${ }^{12}$

Menurut Faturrahman Djamil kebutuhan dlarûriyyah itu ada lima, yaitu: ${ }^{13}$

1. Memelihara agama (hifzh al-dîn);

2. Memelihara jiwa (hifzh al-nafs);

3. Memelihara akal (hifzh al-'aql);

4. Memelihara keturunan (hifzh al-nasl); dan

5. Memelihara harta (hifzh al-mâl).

Islam telah menetapkan untuk setiap urusan dlarûri merupakan hukum-hukum yang mencapai akan eksistensinya dan pemeliharaannya yang disebut hukum dlarûri (aturan dlarûri). Mengenai urusan dlarûri sering disebut sebagai kebutuhan primer. Dalam teori motivasi A. Maslow, sebagaimana dikutip oleh Buchari Alma, telah membagi kebutuhan primer menjadi lima bagian, yaitu: ${ }^{14}$

1. Kebutuhan fisiologis, yaitu kebutuhan terhadap makanan, minuman, dan istirahat;

2. Kebutuhan terhadap rasa aman san keselamatan;

12 Atang Abdul Hakim, Filsafat Hukum Islam (Bandung: Pustaka Setia. 1997), hlm. 52.

13 Fathurrahman Djamil, Filsafat Hukum Islam (Jakarta: Logos Wacana Ilmu. 1999), hlm. 128. la mengutip teori maqâshid al-syarî‘ah, al-Syâtibî dalam kitab al-Muwâfaqât.

14 Buchari Alma, Kewirausahaan (Bandung: Alfabeta. 2004), hlm. 65 . 
3. Kebutuhan terhadap afiliasi, cinta dan sosial;

4. Kebutuhan terhadap pengakuan, penghargaan, dan kedudukan; dan

5. Kebutuhan akan aktualisasi diri.

Dalam melaksanakan ekonomi dalam jual beli agar sesuai dengan tujuan dan prinsip dasar fiqih muamalah, yakni asas-asas muamalah yang meliputi pengertianpengertian dasar yang dikatakan sebagai teori yang membentuk hukum muamalah. Dalam konteks ini, Juhaya S. Praja menjelaskan asas-asas muamalah sebagai berikut: ${ }^{15}$

1. Asas tabâdul al-manâfi', yang berarti bahwa segala bentuk muamalah harus memberikan keuntungan dan manfaat bagi pihak-pihak yang terlibat;

2. Asas pemerataan, adalah menerapkan keadilan dalam bidang muamalah yang menghendaki agar harta itu tidak hanya dikuasai oleh segelintir orang sehingga harta itu harus terdistribusikan secara merata dalam masyarakat, baik kaya maupun miskin;

3. Asas suka sama suka, yaitu bahwa setiap bentuk muamalah antar individu atau antar pihak harus berdasarkan kerelaan masing-masing;

4. Asas 'adâmul gharâr, bahwa pada setiap bentuk muamalah tidak boleh ada gharâr, yaitu tipu daya atau sesuatu yang menyebabkan salah satu pihak merasa dirugikan oleh pihak yang lainnya, sehingga mengakibatkan hilangnya unsur kerelaan salah satu pihak dalam melakukan suatu transaksi atau perikatan;

5. Asas al-bir wa al-taqwâ, yaitu menekankan bentuk muamalah yang termasuk kategori suka sama suka ialah sepanjang bentuk muamalah dan pertukaran manfaat itu dalam rangka pelaksanaan saling menolong antar sesama manusia untuk asas al-bir wa al- taqwâ, yakni kebajikan dan ketakwaan dalam berbagai bentuknya; dan

6. Asas musyarakah, yaitu kerjasama antar pihak yang saling menguntungkan, bukan saja bagi pihak yang terlibat melainkan bagi keseluruhan masyarakat manusia.

Berpegang pada prinsip-prinsip dan asas-asas hukum ekonomi Islam di atas, dapat diambil beberapa rumusan sebagai beri-

15 Juhaya S. Praja, Filsafat Hukum Islam (Bandung: Yayasan Piara. 1997), hlm. 113. kut: Pertama, hikmah melakukan akad dan pemilikan harta dengan cara jual beli atau berdagang hendaknya berpegang kepada prinsip-prinsip dan asas-asas ekonomi Islam untuk tujuan sesuai dengan syariat Islam; Kedua, setiap jenis akad dan pemilikan harta hendaknya memperhatikan unsur-unsur yang menjadi prinsip-prinsip dan asas-asas muamalah, baik dalam jual beli maupun akad-akad lainnya, demi terjaminnya harta yang dimiliki menjadi halal; dan Ketiga, tujuan akad dan pemilikan harta hendaknya bukan hanya ditujukan untuk pemilikan harta dan keuntungan yang banyak, tetapi juga harus memperhatikan manfaat dan madaratnya. Karenanya, Islam telah memberikan aturan-aturan yang sempurna dalam bidang muamalah demi tercapainya kemaslahatan hidup manusia.

\section{Keabsahan Akad Transaksi Bisnis MLM Menurut Hukum Perikatan Islam}

Kewenangan negara dalam mengatur invetasi pasar dan mengendalikan ekonomi rakyat dapat dianalisis melalui taqnîn alahkâm yang dikaji dari perspektif ilmu hukum perikatan Islam. Aplikasi hukum perikatan Islam (nazhâriyyat al-'uqûd) tentang transaksi bisnis MLM ke dalam peraturan dan perundang-undangan di Indonesia dapat dilakukan melalui transformasi hukum (taqnîn al-ahkâm). Istilah taqnîn itu sendiri berasal dari kata qânûn yang dalam bahasa Arab diambil dari bahasa Suryani yang berarti "alat pengukur" atau "kaidah". Dalam bahasa Arab kata kerjanya qanna yang artinya membuat hukum (to make law/to legislate). Kemudian kata qânûn dapat dirartikan dengan hukum (law), peraturan (rule/regulation), atau undang-undang (statute/code). ${ }^{16}$

Jika ditelaah lebih komprehensif, ada beberapa istilah yang tampaknya memiliki konotasi hampir sama dengan qânûn, antara lain: 1) hukm jamaknya ahkâm; 2) qâ'idah jamaknya qawâ'id; 3) dustûr; 4) dlâbithah jamaknya dlawâbith; dan 5) rasm jamaknya rusum. Sedangkan al-Mâwardî (W. 450 H/1058 M), al-Ahkâm al-Sulthâniyyah, telah menjelaskan istilah qânûn dalam beberapa

16 A. J. Wensink, CD The Encyclopedia of Islam (New Ed.) Jilid IV, hlm. 558 dan A. Qadri Aziziy, Eklektisisme Hukum Islam: Kompetisi antara Hukum Islam dan Hukum Umum (Yogyakarta: Gama Media Press. 2002), hm. 57. 
kesempatan dan mempunyai konotasi atau spesifikasi yang tidak selalu sama. Misalnya, ketentuan hukum dalam wilayah politik atau hukum publik dijelaskan pada halaman 32 (qawânîn al-siyâsah), menjaga hukum publik yang berdasarkan syari'ah dan memelihara hukum agama/ibadah dijelaskan pada halaman 33 (Hifzh al-qawânîn al-syar'iyyah wa harasât al-ahkâm al-dîniyah) dan undangundang dijelasakan pada halaman 215 (alqawânîn al-muqâranah). ${ }^{17}$

Selanjutnya, dari kata qânûn tersebut berubah menjadi kata taqnîn yang berarti mengundangkan (legislation, tranformation), dan dalam istilah lain dikenal pula dengan kodifikasi atau unifikasi. Dengan kata lain, yang dimaksud dengan taqnîn adalah suatu proses dalam mentransformasikan suatu peraturan/hukum yang tidak tertulis kepada sistem peraturan/hukum yang tertulis. Hal tersebut tidak dapat dipisahkan dari pemahaman tentang ajaran hukum kodifikasi yang sangat dominan dalam kajian filsafat hukum. ${ }^{18}$

Paham kodifikasi bukan hanya berpengaruh besar dalam lingkup pemikiran hukum Islam, tetapi juga erat kaitannya dengan Ilmu Hukum Tata Negara dan Politik Islam (siyâsah al-syar'iyyah), dan termasuk pula di dalamnya politik ekonomi Islam (siyâsah almâliyyah). Pendek kata, kajian MLM dalam hukum perikatan Islam (nazhâriyyat al-'uqûd) merupakan bagian integral dari pembahasan tentang hukum ekonomi Islam (figh almu'âmalah). Hal ini merupakan penegasan penulis terhadap penjelasan pada bab-bab sebelumnya, yakni bisnis MLM sangat erat kaitannya dengan kajian tentang obyekobyek hukum ekonomi Islam (mu'âmalah almadiyah) dan etika ekonomi Islam (mu'âmalah al-adabiyah).

Dilihat dari segi filsafat hukum Islam, istilah kodifikasi atau unifikasi undangundang juga erat kaitannya dengan filsafat positivisme yang berpengaruh kuat terhadap proses pembuatan perundang-undangan. Paham ini menjelaskan hukum tersebut dalam teori hukum yang disebut dengan kon-

17 Abû Hassan al-Mâwardî, al-Ahkâm al-Sulthâniyyah (Kairo: Musthafâ al-Bâb al-Halabî. 1973), hlm. 3233 dan 215.

18 A. Qadri Azizy, Eklektisisme Hukum Islam. hlm. $57-58$. stitusi. Misalnya, menurut stufentheorie mazhab Wina (Adolf Merkel dan Carl Schmith, keduanya merupakan pengikut aliran positivisme) menyatakan bahwa suatu hukum akan diakui, dipatuhi, dan diyakini memiliki kekuatan, apabila hukum tersebut telah tertulis dan dikodifikasikan ke dalam peraturan dan perundang-undangan.

Dalam perkembangannya menurut mazhab Wina, konstitusi negara pun hendaknya berbentuk abstrak dan universal, seperti dituangkan dalam bentuk Undang-Undang Dasar (UUD), yang selanjutnya diikuti pula dengan peraturan-peraturan turunannya yang lebih spesifik, konkret, dan praktis. Hal ini disebabkan dasar pemahaman teori konstitusi adalah suatu sistem hukum yang tersusun secara hierarkies-piramidal, abstrak, dan bersifat umum. Namun pandangan ini telah jauh berubah seiring dengan semakin dominannya pengaruh paham kodifikasi dalam lingkup pemikiran hukum modern. ${ }^{19}$

Untuk melegislasikan hukum perikatan Islam (nazhâriyyat al-'uqûd) yang erat kaitannya dengan transaksi bisnis MLM ke dalam peraturan dan perundang-undangan di Indonesia salah satunya dapat dilakukan melalui pendekatan politik hukum (siyâsah al-syar'iyyah). Dalam konteks sekarang, politik hukum dimaknai pula sebagai bentuk kebijakan hukum yang dianut oleh pemerintah dan kesadaran hukum masyarakat suatu negara untuk patuh kepada hukum negara. ${ }^{20}$ Sehingga muncul pandangan bahwa hukum lahir dari proses politik dan/atau sebaliknya politik lahir dari proses hukum. Kedua pandangan yang berbeda tersebut telah jauh mempengaruhi prosedur pengambilan keputusan tertinggi dalam wilayah kekuasaan atau negara. ${ }^{21}$

Namun demikian, antara qânûn dan taqnîn hukum perikatan Islam ke dalam sistem hukum negara tampaknya tidak bisa dibatasi oleh sketsa pemikiran teoritis yang bersifat individual dan kaku seperti halnya perubahan

19 Lili Rasyidi dan Arif Sidharta, Filsafat Hukum Madzhab dan Refleksinya (Bandung: Rosdakarya. 1997), hlm. 37-38.

20 Isma'il Sunny, Tradisi dan Inovasi Keislaman di Indonesia dalam Bidang Hukum Islam, dikutip dari Bunga Rampai Peradilan Islam di Indonesia (Bandung: Ulul Albab Press. 1997), jilid I, hlm. 40-42.

21 Teuku Mohammad Radhie, Politik dan Pembaharuan Hukum (Jakarta: LP3ES. 1973), hlm. 4. 
pemahaman dari syariat kepada fiqih. Karena antara qânûn dan taqnîn mencakup dua cara pandang yang saling tarik-menarik. Berbicara qânûn berarti substansi masalah berbicara seputar produk hukum Islam yang dipengaruhi oleh pola pikir, tradisi dan politik hukum suatu masyarakat. Sedangkan taqnîn berarti substansi pembicaraan menyangkut urusan dengan ilmu politik atau hukum tata negara.

Mengacu kepada uraian di atas, untuk memahami qânûn hukum perikatan Islam ke dalam peraturan dan perundang-undangan tampaknya dapat pula dikaji melalui pendekatan tafsir hukum, sebab tafsir hukum berbicara tentang bagaimana memahami suatu produk hukum. Sedangkan taqnîn hukum perikatan Islam ke dalam peraturan perundang-undangan tampaknya juga lebih tepat jika dipahami dengan tafsir politik, sebab taqnîn merupakan proses legislasi suatu hukum dalam wilayah hukum tata negara. Pendek kata, keduanya tidak dapat diasumsikan hanya dalam batas-batas teori ilmu hukum bisnis semata, melainkan terkait pula dengan ilmu hukum tata negara.

Mengacu kepada uraian tersebut, transformasi hukum perikatan Islam (nazhâriyyat al-'uqûd) mengenai transaksi bisnis MLM ke dalam peraturan dan perundang-undangan di Indonesia dapat dianalisis melalui klusul materi hukum yang terdapat pada sejumlah peraturan yang disebutkan sebelumnya, di antaranya: Keputusan Menteri Perdagangan RI Nomor 32 Tahun 2000, Peraturan Menteri Perdagangan RI Nomor 13 Tahun 2006, Peraturan Presiden RI Nomor 111 Tahun 2007, dan Peraturan Presiden RI Nomor 36 Tahun 2010.

Kaitannya dengan keabsahan transaksi bisnis MLM, sebelum tahun 2000, di Indonesia tampaknya belum ada Undang-Undang yang secara khusus mengatur tentang transaksi bisnis MLM, Network Marketing, atau Scheme Pyramid Marketing. Berdasarkan hasil penelusuran penulis dari berbagai sumber, perkembangan regulasi bisnis MLM memang belum ada sebelum tahun 2000. Hal ini didasarkan kepada penjelasan yang dikemukakan oleh Yus Ariyanto, Lily Evelina, dan Taty Haryati, ${ }^{22}$ yang dilansir dalam majalah

22 Lihat pernyataan Yus Ariyanto, Lily Evelina, dan Taty Haryati, "Segera Terbit: Rambu-Rambu Bisnis
Trust bahwa "pada suatu hari, mungkin seorang kawan mengontak anda dengan bersemangat. Ayo kita ketemu. Tidak lama lagi, paling juga setengah jam". la berkata: "ada suatu peluang bisnis yang bisa mengubah nasib dalam sekejap secara signifikan. Mungkin Anda bakal segera tergiur: siapa yang tidak mau peruntungannya membaik".

Dalam penjelasannya ditegaskan bahwa ketiganya tengah melakoni hal lazim dalam praktik bisnis MLM, yakni usaha merekrut anggota baru. Perluasan jaringan memang menjadi modal utama bisnis ini. Jika dianalisis dari pernyataan tersebut, jelas usaha lembaga bisnis ini menggunakan cara MLM, meskipun pada kenyataannya itu semua sekadar kamuflase dari suatu tindak penipuan.

Untuk menertibkan aktivitas MLM di Indonesia, pemerintah tampaknya mulai responsif, terutama pada awal tahun 2000. Sebagai contoh, dikeluarkannya Keputusan Menteri Perindustrian dan Perdagangan RI Nomor: 73/MPP/Kep/3/2000 tentang Ketentuan Kegiatan Usaha Penjualan Berjenjang. Menurut Arsul Sani, ${ }^{23}$ lahirnya Kepmen Nomor: 73/2000 tersebut dikatakan agak terlambat. Sebab, kegiatan usaha ini tampaknya sudah ada sejak dekade 1980-an. Pelopornya adalah PT. Avon Indonesia. Selanjutnya, disusul Tupperware, Amway, dan CNI yang Indonesia tulen.

Setelah tiga tahun berlaku, tepatnya pada tahun 2003, muncul kebutuhan untuk merevisi regulasi tersebut, yakni setelah berlaku efektif ternyata ditemukan sejumlah masalah, Misalnya, istilah "kegiatan usaha penjualan berjenjang", selalu menimbulkan konotasi MLM. Padahal, yang namanya direct selling menurut kamus adalah selling direct to consumer. Dengan kata lain, MLM tidak melalui gerai atau toko. Pendek kata, direct selling bukan hanya MLM, tapi juga meliputi single level marketing (SLM). ${ }^{24}$

MLM", dalam http://www.majalahtrust.com/fokus/fokus/222.php, diakses tanggal 12 Juni 2010.

23 Menurut Arsul Sani (Ketua Tim Perumus Kepmen), menyatakan bahwa sesungguhnya Indonesia telah memiliki regulasi menyangkut soal itu, yaitu Kepmen Perindustrian dan Perdagangan Republik Indonesia Nomor: 73/MPP/Kep/3/ 2000 tentang Ketentuan Kegiatan Usaha Penjualan Berjenjang.

24 Arsul Sani (Pengacara dari Karim Sani Law Firm) yang berkedudukan di Jakarta, yang fokus dalam 
Jika diamati lebih jauh, potensi kendala tersebut membuat pemerintah berusaha mencari jalan ke luar. Sinyal perubahan maksimal persentase modal asing di MLM pun disampaikan Departemen Perdagangan sebagaima tampak pada tabel di bawah ini: ${ }^{25}$

\begin{tabular}{|c|c|}
\hline \multicolumn{2}{|c|}{$\begin{array}{l}\text { Perkembangan Regulasi Modal MLM di } \\
\text { Indonesia }\end{array}$} \\
\hline Regulasi & Ketentuan Modal \\
\hline $\begin{array}{c}\text { Kepmendag Nomor: } \\
73 / 2000\end{array}$ & Tidak ada ketentuan \\
\hline $\begin{array}{l}\text { Permendag Nomor: } \\
13 / 2006\end{array}$ & $>$ Rp. 500 juta \\
\hline $\begin{array}{l}\text { Perpres Nomor: } \\
111 / 2007\end{array}$ & $\begin{array}{l}\text { Lokal Rp. } 2 \text { miliar dan } \\
\text { asing Rp. } 5 \text { miliar }\end{array}$ \\
\hline $\begin{array}{l}\text { Perpres Nomor: } \\
36 / 2010\end{array}$ & > Rp. 10 miliar \\
\hline
\end{tabular}

Sumber: Dari berbagai sumber Tahun 2009

Dalam Permendag Nomor: 32/2008 tentang Penyelenggaraan Kegiatan Usaha Perdagangan dengan Sistem Penjualan Langsung diatur larangan bagi perusahaan yang telah memiliki SIUPL untuk menawarkan barang dan jasa yang bertentangan dengan keadaan sebenarnya, menawarkan barang secara paksa, menawarkan barang yang sesuai dengan Undang-Undang Perlindungan Konsumen, mendapatkan keuntungan melalui iuran keanggotaan atau pendaftaran mitra usaha secara tidak wajar.

Regulasi tersebut juga melarang MLM menjual barang yang tidak punya tanda daftar dari instansi teknis, menerima pendaftaran keanggotaan sebagai mitra usaha dengan nama yang sama lebih dari satu kali, memaksa mitra usaha membeli barang dalam jumlah besar yang melebihi kemampuannya dalam menjual, memasarkan barang di luar sistem penjualan langsung. Selain itu,

pembahasan regulasi mengenai MLM di Indonesia pada awal tahun 2000.

25 Penulis melacak data perkembangan regulasi tentang MLM di Indonesia mengacu kepada data yang dipublikasikan dalam http://www.deperindag.go.id diakses 10 Juni 2010. penjualan langsung semacam money game dan pyramida juga dilarang melakukan usaha perdagangan yang terkait dengan penghimpunan dana masyarakat, membentuk jaringan pemasaran terlarang dengan nama atau istilah apa pun, menjalankan usaha perdagangan di luar SIUPL, menjual barang yang label produknya tidak tercantum nama perusahaan yang memasarkan dengan sistem penjualan langsung.

Berdasarkan uraian di atas, penulis merumuskan pokok-pokok pikiran sebagai berikut: Pertama, regulasi bisnis MLM di Indonesia tampaknya sudah berkembang sejak 1980-an, namun baru resmi diatur sejak tahun 2000 tepatnya melalui Kepmendag Nomor: 73/2000 tentang izin penjualan langsung; Kedua, pemerintah Indonesia hanya mengatur MLM dari segi modal dalam dua kategori yakni MLM Lokal Rp. 2 miliar dan MLM Asing Rp. 5 miliar; dan Ketiga, setelah dialihkan fungsi pengawasan MLM dari Kementerian Perdagangan ke BKPM, tahun 2010 direncanakan aturan dari segi modal untuk MLM Lokal Rp. 5 miliar dan MLM Asing Rp. 10 miliar.

\section{E. Keabsahan Transaksi Bisnis MLM Menurut Teori Hukum Perikatan Islam}

Dalam fikih tidak dikenal istilah MLM, namun dikenal teori distribusi salah satunya adalah jual beli ( $a$ l-bay') sebagaimana disebut dalam QS. al-Baqarah 275. Praktik jual beli dilakukan dengan berbagai cara, baik secara langsung maupun tidak langsung. ${ }^{26}$ Hukum kebolehan jual beli didasarkan kepada alQuran dan Sunnah yang melarang praktikpraktik riba dalam setiap transaksi. Oleh karena itu, setiap transaksi hendaknya diawali dengan niat ${ }^{27}$ yang baik dan dilaksanakan menurut praktik atau tata cara akad yang baik pula (kemaslahatan). ${ }^{28}$

26 Muhammad Sayyid Thanthâwî, Mưâmalat alBunûk wa Ahkâmuhâ al-Syar'iyyah (Mesir: Dâr al-Nahdlah. 1977), hlm. 121.

27 Menurut teori niat, lafazh yang diucapkan oleh dua orang yang bertransaksi sangat menentukan keabsahan transaksinya. Hal ini didasarkan pada kaidah "al-'Ibratu fî al-'uqûd li al-maqâshid w al-ma'ânî li alfâzhi wa al-bayân" (akad transaksi itu merupakan maksud dan niat, bukan lafadz dan pernyataan). Lihat dalam Juhaya S. Praja, Teori-teori Hukum. hlm. 159-160.

28 Menurut teori pemeliharaan maslahat (nazhâriyyat al-mashlahah), setiap transaksi bisnis hendaknya 
Untuk menjelaskan hukum transaksi bisnis MLM, penulis juga meng-gunakan teori perubahan hukum melalui pendekatan sejarah dan sosiologi hukum. Dilihat dari sejarahnya, praktik transaksi jual beli MLM merupakan model inovasi bisnis di abad modern sebagai pengembangan dari praktik jual beli yang sebelumnya dikenal dengan tukarmenukar (barter). Dalam masyarakat modern, transaksi jual beli bukan hanya dilakukan secara langsung (direct selling), akan tetapi juga dilakukan secara tidak langsung (indirect selling). Keduanya dibenarkan selama tidak menyalahi prinsip-prinsip, asas-asas, syarat-syarat, rukun-rukun, dan etika bisnis menurut syara'.

Hukum transaksi bisnis MLM sangat erat kaitannya dengan cara masyarakat memahami suatu hukum. Hukum Islam bukan hanya dipahami sebagai norma hukum yang hidup dan dipelihara dalam berbagai dimensi kehidupan masyarakat, tetapi juga menjadi alat pengendali masyarakat. Hal didasarkan kepada kaidah fikih yang berbunyi: "perubahan hukum itu berdasarkan perubahan zaman, tempat dan keadaan". 29 Teori perubahan hukum Islam ini relevan dengan teori perubahan hukum, bahwa hukum yang baik adalah hukum yang dibuat sesuai dengan situasi dan kondisi masyarakat bagi tujuan perubahan sosial (law as a tool of social engineering). ${ }^{30}$

Keterkaitan hukum bisnis Islam dan pemberlakuannya dalam masyarakat muslim mendukung asumsi bahwa kehidupan manusia pada kenyataan konkret dikuasai oleh pelbagai aturan hukum disamping oleh kaidah-kaidah sosial lainnya. ${ }^{31}$ Demikian halnya dengan perkembangan teori-teori hukum juga telah melahirkan kaidah-kaidah hukum yang bersifat normatif bagi berlakunya suatu hukum. Soerjono Soekanto memberikan beberapa alasan: ${ }^{32}$ Pertama, kaidah hukum berlaku secara yuridis apabila penentu-

mempertimbangkan tujuan maslahat dan dampak madaratnya. Ibid. hlm. 163-164.

29 Ibn Qayyim al-Jawziyyah, I'lâm al-Muwaqqi'în (Beirut: Dâr al-Fikr. t.th.), hlm. 118.

30 Teori hukum ini diadopsi dari teori perubahan sosial yang dikemukakan oleh Rosque Pound. Lihat Lili M. Rasjidi dan Arief Sidarta, Filsafat Hukum Mazhab dan Repleksinya (Bandung: Rosda Karya. 1993), hlm. 13.

31 Ibid.

32 Soerjono Soekanto, Sosiologi Hukum dalam Masyarakat (Jakarta: Rajawali Press. 1982), hlm. 13. nya didasarkan atas kaidah yang lebih tinggi tingkatannya, ${ }^{33}$ atau menurut cara yang telah ditetapkan, atau apabila menunjukkan hubungan keharusan antara suatu kondisi dan akibatnya; Kedua, kaidah hukum berlaku secara sosiologis apabila hukum tersebut efektif, artinya dapat dipaksakan keberlakuannya oleh penguasa terhadap masyarakat (teori kekuasaan), atau diterima dan diakui keberlakuannya oleh masyarakat (teori pengakuan); dan Ketiga, kaidah hukum berlaku secara filosofis, artinya sesuai dengan cita-cita hukum sebagai nilai positif yang tertinggi.

Di samping itu, terjadinya pergeseran fungsi kaidah hukum bisnis dalam masyarakat ternyata tidak dapat berjalan sendiri, karena dipengaruhi oleh corak pemahaman hukum. Sekurang-kurangnya ada empat faktor yang menyebabkan terjadinya perubahan kaidah hukum: ${ }^{34}$ Pertama, kaidah hukum atau peraturan itu harus sistematis dan tidak bertentangan baik secara vertikal maupun secara horisontal, serta disesuaikan dengan persyaratan yuridis yang telah ditentukan; Kedua, penegak hukum harus memiliki pedoman tertulis yang menyangkut ruang lingkup tugas, batas-batas kewenangan dalam pengambilan kebijakan; Ketiga, adanya fasilitas yang diharapkan menjadi pendukung pelaksanaan kaidah hukum yang telah ditetapkan. Fasilitas ini dapat berupa sarana fisik yang berfungsi untuk mencapai tujuan hukum; dan Keempat, masyarakat dalam hal ini menjadi faktor yang dominan berkaitan dengan tingkatan atau derajat kepatuhan atau ketaatan terhadap hukum.

Berkenaan dengan hal tersebut, aplikasi nahzariyyat al-'uqûd dalam berbagai tentang praktik bisnis jual beli dengan sistem MLM dalam hukum perikatan Islam di Indonesia telah digaransi dalam peraturan perundangundangan. Salah satunya adalah UndangUndang Perbankan Nomor 7 Tahun 1992 yang direvisi menjadi Undang-Undang Nomor 10 Tahun 1998 menjadi landasan hukum bagi pelaksanaan transaksi bisnis berdasar-

33 Hans Kelsen telah menjelaskan dalam ajaran stufen theorie bahwa hukum merupakan hierarki. Lihat dalam Lili Rasjidi, Dasar-dasar Filsafat Hukum (Bandung: Alumni. 1985), hlm. 4

34 Soerjono Soekanto, Sosiologi Hukum. hlm. 1418. 
kan prinsip-prinsip syari'ah. Oleh karena itu, nazhâriyyat al-'uqûd menjadi pijakan untuk melakukan transaksi bisnis MLM menurut hukum perikatan Islam.

Adapun persoalan paling krusial dalam tulisan ini adalah keabsahan tarnsaksi bisnis MLM di Indonesia saat ini termasuk dalam kategori gharar dan cenderung ilegal, karena banyak yang tidak mengikuti ketentuan peraturan perundang-undangan yang berlaku. Hal ini dapat dibuktikan dengan beberapa indikator sebagai berikut:

Pertama, bisnis MLM tidak tersentuh oleh pajak. Berdasarkan Undang-Undang Perpajakan setiap transaksi bisnis hendaknya dikenai pajak sesuai dengan ketentuan yang berlaku. Namun dalam praktiknya, para pelaku bisnis MLM tidak tersentuh pajak. Jika demikian secara yuridis, bisnis MLM bisa dijerat sebagai bisnis illegal;

Kedua, bisnis MLM tidak tersentuh oleh Hak atas Kekayaan Intelektual (HAKI). Berdasarkan Undang-Undang HAKI setiap transaksi bisnis hendaknya mendaftarkan hak kekayaan intelektual di Kementerian Hukum dan HAM. Namun dalam praktiknya, banyak bisnis MLM yang tidak tidak terdaftar di Kementerian Hukum dan HAM. Jika demikian secara yuridis, bisnis MLM bisa dijerat sebagai bisnis illegal;

Ketiga, bisnis MLM saat ini hanya berlindung kepada Permendag Nomor: 32/2008 tentang Penyelenggaraan Kegiatan Usaha Perdagangan dengan Sistem Penjualan Langsung. Namun peraturan tersebut masih banyak memiliki kelemahan dan kontradiksi dengan Kitab Undang-Undang Hukum Dagang yang berkenaan dengan kepemilikan aset perusahaan, klaim perlindungan usaha yang tidak jelas, dan resiko kerugian usaha bagi pelaku bisnis MLM. Sudah barang tentu kelemahan-kelemahan tersebut berakibat kepada lemahnya peraturan yang mengatur legalisasi bisnis MLM di Indonesia; dan

Keempat, bisnis MLM saat ini banyak yang menggunakan "kedok" bagi hasil berdasarkan syari'ah, namun dalam praktik transaksi bisnisnya banyak yang mengabaikan syarat dan rukun serta prinsip-prinsip dan asas-asas hukum perikatan Islam. Sehingga secara syariat, praktik bisnis MLM termasuk dalam kategori jual beli gharar dan maysir yang dikategorikan "haram".

Berdasarkan uraian tersebut di atas, maka praktik transaksi bisnis MLM hanya dibolehkan dalam hukum perikatan Islam apabila ia telah terpenuhi dari segi prinsipprinsip, asas-asas, syarat-syarat, rukun-rukun, dan etika bisnis syari'ah. Sebaliknya, jika ketentuan syari'ah tersebut diabaikan, maka praktik transaksi bisnis MLM dilarang karena terbuka peluang untuk terjebak pada unsur riba, gharar, dan maysir. Pada gilirannya, dapat dikatakan di sini bahwa keabsahan setiap transaksi bisnis MLM dalam hukum perikatan Islam adalah harus terpenuhinya semua prinsip, asas, syarat, rukun, dan etika bisnis, serta terpeliharanya tujuan syariat yang ada dalam produk hukum perikatan Islam.

\section{F. Penutup}

Praktik transaksi bisnis MLM syari'ah pada umumnya memiliki beberapa keuntungan, antara lain: Pertama, adanya jaminan keuntungan hasil investasi yang konkret, terukur, dan rasional disebabkan hasil yang diperoleh tergantung kepada usaha yang dilakukan; Kedua, adanya jaminan aspek hukum dan keamanan investasi, karena setiap member juga ikut merasa memiliki terhadap perusahaan; Ketiga, transaksi dapat dilakukan dalam rentang waktu jangka pendek dan jangka panjang, karena bisnis MLM tidak dibatasi oleh ruang dan waktu. la dapat dilakukan melalui tatap muka (face to face) dan tidak langsung (online); dan Keempat, adanya jaminan kesetaraan hak dan kewajiban bagi pihak-pihak yang melakukan transaksi.

Namun demikian penulis melihat bahwa kebanyakan praktik transaksi bisinis MLM saat ini sebagaimana disoroti oleh MUI DKI dalam figh Indonesia Himpunan Fatwa MUI DKI Jakarta adalah barang-barang yang diperjualbelikan dalam sistem MLM menggunakan harga yang jauh lebih tinggi dari harga wajar, maka hukumnya haram, karena secara tidak langsung pihak perusahaan telah menambahkan harga yang dibebankan kepada pihak pembeli sebagi sharing modal dalam akad syirkah (kemitraan) mengingat pembeli sekaligus akan menjadi member perusahaan 
yang apabila ia ikut memasarkan akan mendapat keuntungan estafet.

Dengan demikian penulis dapat menegaskan, bahwa praktik transaksi bisnis MLM semacam ini jelas mengandung unsur kesamaran (gharar) atau penipuan (maysir) karena terjadi kekaburan antara akad jual beli, syirkah, dan mudlarabah, karena pihak pembeli sesudah menjadi member juga berfungsi sebagai pekerja yang memasarkan produk perusahaan kepada calon pembeli atau member baru.

\section{Daftar Pustaka}

Alma, Buchari. 2004. Kewirausahaan. Bandung: Alfabeta.

Ariyanto, Yus dkk. "Segera Terbit: RambuRambu Bisnis MLM", dalam http://www.majalahtrust.com/fokus/fokus/222. php, diakses tanggal 12 Juni 2010.

Azizy, A. Qadri. 2002. Eklektisisme Hukum Islam: Kompetisi antara Hukum Islam dan Hukum Umum. Yogyakarta: Gama Media Press.

Basri, Ikhwan Abidin. "Teori Akad dalam Fikih Muamalah", artikel dalam http://www.fossei.4t.com/Artikel14.htm, diakses tanggal15 Januari 2010.

Basyir, Ahmad Azhar. 1994. Refleksi Atas Persoalan Keislaman. Bandung: Mizan.

Djamil, Fathurrahman. 1999. Filsafat Hukum Islam. Jakarta: Logos Wacana IImu.

Hakim, Atang Abdul. 1997. Filsafat Hukum Islam. Bandung: Pustaka Setia.

Hoesen, Nibra. 2006. Pengerrtian Akad dalam Transaksi Syariah. Kuala Lumpur: INCEIF.

Hosen, Nibra. tim penyunting: Muhammad Firdaus NH, Sofiniah Ghufron, Muhammad Aziz Hakim, Mukhtar Alshodiq. Briefcase Book Edukasi Professional Syariah, Cara Mudah Memahami Akadakad Syariah. Kuala Lumpur: INCEIF.

Jawziyyah, Ibn Qayyim al-. t.th. I'lâm alMuwaqqiînn. Beirut: Dâr al-Fikr.
Mâwardî, Abû Hassan al-. 1973. al-Ahkâm alSulthâniyyah (Kairo: Musthafâ al-Bâb alHalabî.

Praja, Juhaya S. "Hierarki Hukum Islam". diambil dari Hasil Materi Kuliah Filsafat Hukum Islam semester II-III tahun 1999 di PPS IAIN SGD Bandung.

Praja, Juhaya S. "Rekosntruksi Paradigma Ilmu: Titik Tolak Pengembangan Ilmu Agama dan Universalitas Hukum Islam". Orasi Ilmiah Pengukuhan Guru Besar Madya Filsafat Hukum Islam tanggal 1 April 2000 di IAIN Sunan Gunung Djati Bandung.

Praja, Juhaya S. 1997. Filsafat Hukum Islam. Bandung: Yayasan Piara.

Radhie, Teuku Mohammad. 1973. Politik dan Pembaharuan Hukum. Jakarta: LP3ES.

Rasjidi, Lili M. 1985. Dasar-dasar Filsafat Hukum. Bandung: Alumni.

Rasjidi, Lili M. dan Arief Sidarta. 1993. Filsafat Hukum Mazhab dan Repleksinya. Bandung: Rosda Karya.

Rasyidi, Lili dan Arif Sidharta. 1997. Filsafat Hukum Mazhab dan Refleksinya. Bandung: Rosdakarya.

Shiddiqie, Hasbi ash-. 1982. Fakta Keagungan Syariat Islam. Jakarta: Bulan Bintang.

Soekanto, Soerjono. 1982. Sosiologi Hukum dalam Masyarakat. Jakarta: Rajawali Press.

Soenarjo, dkk. 1987. al-Quran dan Terjemahnya. Jakarta: Depag RI.

Suhendi, Hendi. 2002. Fikih Muamalah. Jakarta: Raja Grafindo Persada.

Sunny, Isma'il. 1997. Tradisi dan Inovasi Keislaman di Indonesia dalam Bidang Hukum Islam. Bandung: Ulul Albab Press.

Thanthâwî, Muhammad Sayyid. 1977. Mu'âmalat al-Bunûk wa Ahkâmuhâ al-Syar'iyyah. Mesir: Dâr al-Nahdlah.

Wensink, A. J. 2001. CD The Encyclopedia of Islam (New Ed.). Leiden: E.J. Brills 